\title{
The Relationship between Organizational Commitment and Work Alienation: A Study on the Health Sector
}

\author{
Örgütsel Bağlılık İle Işse Yabancılaşma Arasındaki İlişki: Sağlık Sektörü Üzerine Bir Araştırma
}

\author{
Rahmah RAHMAH \\ rahmaharsal1991@gmail.com \\ https://orcid.org/0000-0003-1141-6936
}

$\begin{array}{ll}\text { Received } & : 14.12 .2021 \\ \text { Revised } & : 29.12 .2021 \\ \text { Accepted } & : 29.12 .2021 \\ \text { Type of Article } & : \text { Research }\end{array}$

\begin{abstract}
Keywords:

Work Alienation,

Organizational

Commitment,

Health Sector

Alienation, which is built on Hegel's social psychology studies and Karl Marx's philosophical studies, is considered to be an increasingly important problem as an interdisciplinary subject. Work alienation is a state of incompatibility that occurs as a result of the individual's getting distanced from himself/herself and society. It is important to handle this state of incompatibility, which is affected by external and internal factors, from an administrative point of view. In this connection, the purpose of the current study is to determine the level of work alienation of employees and the effect of alienation on the level of organizational commitment. The study employed the questionnaire method to collect data. The population of the study consists of health sector workers in the city of Istanbul. The sample of the study is comprised of 322 people selected from the population by using the random sampling method. Correlation and regression analysis methods were used to determine the interaction between the perceptions of organizational commitment and work alienation. As a result of the analysis, it was determined that there is a negative and significant correlation between work alienation and organizational commitment.
\end{abstract}

\section{Anahtar \\ Kelimeler:}

İşe Yabancılaşma,

Örgütsel Bağlılık,

Sağlık Sektörü

\section{ÖZET}

Hegel'in sosyal psikoloji araştırmalarında ve Karl Marx'ın felsefi çalışmalarında temellenen yabancılaşmanın, disiplinlerarası bir inceleme konusu olarak önemi giderek artan bir sorun olduğu düşünülmektedir. İşe yabancılaşma, bireyin kendinden ve toplumdan uzaklaşması ile ortaya çıkan bir uyumsuzluk durumudur. Dışsal ve içsel faktörlerin etki ettiği bu uyumsuzluk durumunun yönetimsel açıdan ele alınması önemlidir. Bu düşünceden hareketle tasarlanan araştırmanın amacl; çalışanların işe yabancılaşma düzeylerinin ve yabancılaşmanın örgütsel bağlllık düzeyi üzerindeki etkisinin tespit edilmesidir. Araştırmada veri toplama yöntemi olarak anket yönteminden yararlanılmıştır. Araştırmanın evrenini İstanbul ilindeki sağlık sektörü çalışanları oluşturmaktadır. Söz konusu evren içerisinde tesadüfi yöntemle seçilmiş 322 kişi çalışmanın örneklemidir. Örgütsel bağlllık ve işe yabancılaşma algısı arasındaki etkileşimi belirlemek için korelasyon ve regresyon analizi yönteminden yararlanılmıştır. Yapılan analizler sonucunda işe yabancılaşma ile örgütsel bağlllık arasında negatif ve anlamlı bir iliş̧ki olduğu tespit edilmiştir. 


\section{INTRODUCTION}

Nair and Vohra (2010) state that the psychological bond between the individual and the organization has mainly been investigated in relation to the concept of commitment to the organization rather than alienation from work. The psychological distance between the individual and the organization is generally defined as work alienation in the literature (Hirscfield and Field, 2000; Kanungo, 1979). Hirscfield and Field (2000) addressed work centrality and work alienation as separate elements of a general commitment to work. In this regard, Hirschfeld and Feild (2000) define the concept of work alienation as a psychological sense of getting disengaged from work. According to this definition, the concept of work alienation reflects the degree of disengagement and unenthusiastic outlook of the person from the business world. Similarly, Kanungo (1979) handled the concept of work alienation and work involvement as two poles of the same phenomenon and defined work alienation on the basis of the sense of disengagement. Accordingly, work involvement refers to a person's cognitive identification with the work and the perception that the work has the potential to meet the expectations and needs (external and internal) of the person. Work alienation, on the other hand, refers to the psychological and cognitive separation of the person from the work and the perception that the work does not have the potential to meet the expectations and needs (external and internal) of the person (Kanungo, 1979).

As can be seen, studies investigating the concepts of alienation and organizational commitment explain both of these concepts by emphasizing the psychological bond or disengagement between the individual and the organization. In addition, studies in the literature also show that these two variables are closely related to organizational attitudes such as job performance and intention to quit (Az, 2017; Meyer and Allen, 1991; Meyer et al., 2002; Özutku, 2008; Taştan, İşşi and Arslan, 2014; Tummers and Dulk, 2013; Ünsal and Karahan, 2011; Weiner and Vardi, 1980).

The fact that work alienation refers to a psychological separation/disengagement from work and that organizational commitment refers to the strength of the bond established with the organization, as well as the fact that both variables are related to organizational results such as job performance and intention to quit strengthen the possibility of a relationship between these two variables. Studies on the relationship between organizational commitment and work alienation also support this situation.

Tummers and Dulk (2013) revealed that work alienation negatively affects employees' organizational commitment as well as their performance. The meta-analysis study conducted by Chiaburu, Thundiyil, and Wang (2014) showed that although work alienation affects various organizational outputs, it has the strongest effect on organizational commitment. Hirscfield and Field (2000) found that work alienation has a stronger relationship with the emotional commitment dimension of organizational commitment compared to work centrality.

Brannen and Peterson (2009) concluded that work alienation causes employees to stay at work solely for financial reasons. Employees whose interest in the job has decreased stay in this job only for financial reasons, which causes a feeling of alienation. Therefore, work alienation may cause employees to develop continuance commitment, which is related to the cost of leaving the organization, rather than an emotional commitment to identification with the organization and commitment to the organization.

\section{LITERATURE REVIEW}

The review of the literature on organizational alienation and the antecedents and consequences of organizational alienation in relation to some variables is summarized below.

In order to analyze the state of alienation in the tourism sector, a study was conducted on five-star hotel employees (Babür, 2009). According to the results of the study, the alienation levels of the employees were not very high. The author attributes this result to the fact that young people generally work in the tourism sector. It was observed that the alienation of the employees occurred to the greatest extent in the dimension of powerlessness and this is believed to be because employees think that they are not given the right to speak sufficiently. In addition, it is stated that the division of labour, working conditions and management style factors are among the factors affecting the dimension of powerlessness. In addition, it is stated that unfair promotions in the tourism sector cause a significant increase in the dimension of normlessness. The factors affecting the dimension of meaninglessness and normlessness are explained as economic structure, working conditions, management style and work itself.

Banai and Weisberg (2003) examined the levels of alienation among employees in private and public organizations in Russia. The results of the survey conducted on 725 employees working in three private and five public organizations are as follows: The organizational alienation level of the employees working in private 
companies is higher than the employees working in public institutions. On the other hand, it was observed that the alienation levels of the employees with high education level were lower than those of the employees with low education level. The authors, who concluded that alienation levels are higher in male employees, attribute this to the fact that women adapt faster to changing conditions. In addition, it was stated that there is an opposite relationship between organizational alienation and organizational commitment.

A seminal study examining the problem of organizational alienation was carried out by Mauldin (2001). The researcher aimed to determine the attitudes of employees towards organizational alienation, with the idea that humour behaviours can reveal people's subconscious situations. And it was concluded that negative subjective comments made towards the work and the person can cause organizational alienation. Managers' establishing positive relations in the organizational environment seems to be very important in terms of the alienation problem. In a study carried out to determine the causes of alienation, the factors that lead to the emergence of powerlessness, meaninglessness, normlessness and alienation from society are stated to be a division of labour, working conditions, social cultural-economic structure, technological structure and urbanization-industrialization (Büyükyılmaz, 2007). In another study examining the relationship between working conditions and alienation, it is stated that negative working conditions will cause burnout in employees over time and this will cause alienation. According to the results of the study, there is a positive relationship between the satisfaction of the employees regarding the working conditions and burnout. In addition, it is stated that there is a positive relationship between burnout syndrome and alienation (Behar, 2007).

Chiaburu et al. (2014) conducted a meta-analysis study on alienation. The study revealed the antecedents and consequences of alienation. Accordingly, the antecedents of alienation are stated as personality characteristics, role stress (role conflict and role ambiguity), leadership, job design and work environment. The consequences of alienation are summarized as negative results in employee attitudes, absenteeism, health problems and poor performance. The authors, who interpret the antecedents and consequences of alienation, state that alienation will negatively affect the adoption of the job, job satisfaction and commitment (Chiaburu et al. 2014: 33). Mercan (2016), on the other hand, surprisingly, did not find a significant relationship between organizational alienation and organizational commitment in a study conducted on a sample of teachers.

The relationship between leadership and alienation, which Chiaburu et al. (2014) expressed as an antecedent of alienation, is a subject investigated in the study of Banai and Reisel (2007). In the study, the concept of alienation is discussed in two dimensions as individual and social. The study, which examined the relationship between supportive leadership, job characteristics and alienation, was carried out on production facility and hospital employees working in Cuba, Germany, Hungary, Israel, Russia and the United States. As a result of the study, it was concluded that there is a negative relationship between leadership and individual alienation in Cuba, Hungary, Russia and the USA, and there is a negative relationship between leadership and social alienation in Cuba and Hungary. In addition, it is stated that in western countries such as Germany and the USA, alienation is less than in others. The authors explained the reason for different results across the countries on the basis of cultural differences.

Another study dealing with the relationship between leadership and alienation is by Sarros et al. (2002). The aim of the study was to examine the relationship between transformational leadership and transactional leadership, two styles of leadership, and alienation. The study was carried out on 326 employees of a fire department serving in the USA. As a result, the authors found a positive relationship between transactional leadership and alienation and a negative relationship between transformational leadership and alienation. From this point of view, it is stated that organizations can direct the alienation problem with certain leadership styles. In order to determine the relationship between leadership styles, intention to quit and anti-work behaviours, Puni et al. (2016) conducted a study whose sample consisted of bank employees in Ghana. According to the findings of the study, there is a positive relationship between autocratic leadership style, intention to quit and harmful work behaviour and a negative relationship between democratic leadership style, intention to quit and harmful work behaviour. Intention to quit and harmful work behaviour is defined as the organizational consequences of alienation by Nair and Vohra (2012). The relationship between labour turnover, which is another organizational result of alienation, and alienation was investigated in another study on nurses. The study revealed a positive relationship between labour turnover and alienation. In other words, as alienation increases, it is inevitable to experience an increase in the labour turnover rate (Phillips, 2001).

In light of the data obtained from the managers and employees of the lodging businesses operating in Muğla province, it was concluded that the employees perceive the leadership behaviours of the lower-level managers as more control-oriented. Middle managers, on the other hand, have the perception that top managers have more relationship-oriented leadership behaviour. The differences in perceptions of leadership between hierarchical 
levels can be explained through various reasons. As the majority of the employees are young, they are more prone to perceive the instructions coming from lower-level managers with whom they are in direct interaction as a pressure factor, which may lead to the emergence of the perception that control-oriented leadership behaviour is exhibited by these managers. In addition, the fact that the education level and age of lower-level managers are generally lower than those of the upper-level managers might be the reason for them to exhibit control-oriented leadership (Avcı and Topaloğlu, 2009).

In order to determine the relationship between democratic leadership, in which the person-oriented leadership is adopted, and the hierarchy of needs, a study was conducted on the employees of a five-star hotel in Alanya. In this study, the participants expressed that democratic leadership behaviours more positively affected their need for security, their social needs, their need for self-disclosure and their need for self-completion (İnce, 2013). It should not be forgotten that problems experienced in these factors positively affected by democratic leadership behaviours are among the reasons for alienation.

Democratic leadership behaviour was found to be the dominant leadership style in the sample of the employees working in the lodging sector (Al-Ababneh, 2013). On the other hand, the job satisfaction of the employees was found to be not low. Thus, Al-Ababneh (2013) argues that democratic leadership is the appropriate leadership style for the management of hospitality businesses. An important study investigating role conflict and role ambiguity, which are other antecedents of alienation, was carried out by Keller (1975). According to the results of the study carried out by administering a questionnaire to 88 employees in the R\&D department of a public institution operating in the United States, role ambiguity has a significant negative impact on job satisfaction. Similarly, Netemeyer et al. (1995) concluded that role conflict and role ambiguity have a negative effect on job satisfaction, that role conflict directly affects job-related tensions, but role ambiguity does not have such an effect. Furthermore, role conflict, role ambiguity and workload indirectly affect organizational commitment, intention to quit and job satisfaction. According to the results of another study conducted on the employees of the lodging sector, the presence of role ambiguity in the management policies implemented by the managers will increase the employees' intention to quit (Eastham, 2004).

When the national literature is reviewed, it is seen that there are studies examining the relationship between role conflict and role ambiguity and job satisfaction and organizational commitment. In order to investigate the relationship between organizational commitment, job satisfaction and role stress sources, a questionnaire was administrated to managers in 5 large white meat production enterprises operating in Balıkesir province. As a result of the study, it was determined that there is a negative correlation between organizational commitment, role ambiguity and role conflict. In addition to this, it was stated that role conflict and role ambiguity negatively affect job satisfaction (Akar and Yıldırım, 2008).

The results of a study carried out on employees in the food sector in the Eastern Mediterranean Region revealed that the perception of role ambiguity affects job satisfaction and organizational commitment. In this context, it is possible to say that role ambiguity should be eliminated in the organizational environment in order to ensure job satisfaction and increase organizational commitment (Terzioğlu, 2014).

According to the results of a different study conducted to determine the organizational commitment, job satisfaction and tendency to quit, which are the results of alienation, it was concluded that job satisfaction, organizational commitment and alienation affect the tendency to quit. It is stated that the dimensions of normative commitment and self-alienation have a high effect on the tendency to quit (Uysaler, 2010). Contrary to these studies examining the relationship between alienation and organizational commitment, K1liç (2010) reached a surprising result in the study conducted on call centre employees. According to the results of the study, there is a linear and strong correlation between the organizational commitment of the employees and their state of alienation. The reason for such a result might be the fact that the participants may have avoided giving negative answers to the questions posed to measure their alienation due to professional concerns. In addition, Özdevecioğlu and Aktaş (2007) found that there is a positive correlation between life satisfaction and organizational commitment in their study in which they examined the relationship between life satisfaction and organizational commitment levels of the employees working in lodging businesses in Antalya and Nevşehir. Moreover, it was found that the organizational commitment of the employees reduces work-family conflicts that affect their life satisfaction. A study examining the effect of loneliness in business life on organizational commitment was carried out by applying a questionnaire to the employees of a five-star hotel in Didim. As a result of the analysis of the data collected from 156 participants, a negative correlation was found between emotional loneliness in business life and organizational commitment. In the study, although organizational commitment was handled with a three- 
dimensional approach, the normative commitment dimension was excluded from the study due to weak results of the reliability analysis (Ayazlar and Güzel 2014).

The most important factor for the competitive advantage in organizations is to provide quality service. It is obvious that the key element in providing quality service is the personnel. In the tourism industry, where seasonal fluctuations are experienced intensely, sectoral problems such as seasonal employment, exposure to long and irregular working hours and low wages prevent employees from being permanent in enterprises (Güçlü, 2006: 4). Because of the current problems and the importance of the human factor in the tourism sector, the subject of organizational commitment has been widely researched in relation to different variables in the literature. The relationship of organizational commitment with job satisfaction (Namasivayam and Zhao, 2007), life satisfaction (Özdevecioğlu and Aktaş, 2007), organizational learning (Avcı and Küçükusta, 2009), leadership (Yavuz and Tokmak, 2009), organizational justice (Yazıcıŏlu and Topaloğlu, 2009), devotion (Altınöz et al., 2011), organizational stress (Uzun and Yiğit, 2011), work-family conflicts, organizational conflicts (Kavacik et al., 2013), intention to quit (Tnay et al., 2013), mobbing (Y1ldırım et al., 2014; Pelit and K1lıç, 2012), loneliness in business life (Ayazlar and Güzel 2014), staff empowerment (Mete et al., 2015) and organizational loyalty (Yaou et al., 2019) has been investigated in the literature. When the national and international literature on the subject is reviewed, it is seen that the subject to be investigated has been examined in different fields with different variables, and has not been considered as in the model proposed in the current study.

\section{METHODOLOGY}

In this section, the application conducted, the method used, selection of the scales, determination of the sample, data collection and reliability analysis of the scales are presented.

\subsection{Purpose of the Study}

As a result of the developing technology and understanding of competition, the individual, who is the most valuable asset of the organizations, needs to feel safe and should have knowledge about what his/her job completely serves in order to work with maximum efficiency in the organization. In order to help workers in the health sector get rid of the sense of insecurity, cynicism and alienation from the work, first of all, there is a need for the determination of the current situation of the workers by organizations. In the current study, organizational commitment and job alienation levels of individuals employed in various positions by different organizations in the health sector were determined. In this context, the main purpose of the current study is to examine the relationship between the health sector employees' perception of organizational commitment and perception of alienation from work.

\subsection{Research Population and Sample}

The questionnaire method was used as the data collection method in the study. Questionnaires were collected online via Google Forms. Google Docs, a professional online software and MS Word were used to administer the questionnaires, and the data were transferred to SPSS and Excel. The population of the study consists of health sector workers in Istanbul. The sample of the study is comprised of 322 people selected from the population by means of the random sampling method.

\subsection{Scales Used in the Study}

For the current study, studies in the literature on organizational commitment and work alienation were examined and the scale developed by Allen and Meyer in 1990 and given the final shape by Meyer, Allen and Smith in 2000 was used. In addition, the "Work Alienation" scale developed by Mottaz (1981) and adapted to Turkish by Moç (2018) was used. Both of the scales are 3-dimensional.

\subsection{Research Method}

The data of the study were collected by using the questionnaire method. The questionnaire was administered faceto-face and online. In the analysis of the collected data, the SPSS program package was used. First, the demographic data of the participants were analyzed. Then, the reliabilities of the scales used in the study were determined. In order to determine whether the scales and their dimensions were normally distributed, the Kurtosis and skewness values were examined. Correlation and regression analysis methods were employed to determine the interaction between the perceptions of organizational commitment and work alienation. 


\subsection{Hypotheses of the Study}

The following hypothesis was developed to determine the relationship between the perceptions of organizational commitment and work alienation.

$\mathrm{H}_{1}=$ There is a significant correlation between organizational commitment and work alienation.

\subsection{Demographic Information of the Participants}

In this section of the study, demographic information of the 322 participants is presented.

Table 1. Demographic Information of the Participants

\begin{tabular}{|c|c|c|c|}
\hline & Variables & $\mathbf{N}$ & $\mathbf{\%}$ \\
\hline \multirow{3}{*}{ Gender } & Female & 154 & 47.8 \\
\cline { 2 - 4 } & Male & 168 & 52.2 \\
\hline \multirow{3}{*}{ Age } & $18-25$ & 50 & 15.5 \\
\cline { 2 - 4 } & $26-35$ & 193 & 59.9 \\
\cline { 2 - 4 } & $36-50$ & 68 & 21.1 \\
\cline { 2 - 4 } & 51 and older & 11 & 3.4 \\
\hline
\end{tabular}

In Table 1, the demographic information of the participants is shown. Nearly half of the participants are females. Moreover, $59.9 \%$ of the participants are in the age group of 26-35.

\subsection{Reliability and Normality Tests of the Scales Used in the Study}

In this section of the study, the reliability and normality tests of the scales of organizational commitment and work alienation and of their sub-dimensions are given.

Table 2. Reliabilities of the Scales Used in the Study and of their Sub-dimensions

\begin{tabular}{|l|c|c|}
\hline Scales and Sub-dimensions & $\begin{array}{c}\text { Number } \\
\text { of Items }\end{array}$ & $\begin{array}{c}\text { Cronbach's } \\
\text { Alpha }\end{array}$ \\
\hline Organizational Commitment & 18 & .840 \\
\hline Emotional Commitment & 6 & .847 \\
\hline Continuation Commitment & 6 & .820 \\
\hline Normative Commitment & 6 & .776 \\
\hline Work Alienation & 21 & .942 \\
\hline Meaninglessness & 7 & .909 \\
\hline Self-alienation & 7 & .859 \\
\hline Powerlessness & 7 & .906 \\
\hline
\end{tabular}

In Table 2, the reliabilities of the scales used in the current study and of their sub-dimensions are shown. When the reliability test results are examined, it is seen that the scales of organizational commitment and work alienation have "high reliability" $(>.80)$.

Table 3. Descriptive Statistics of the Scales and their Sub-dimensions

\begin{tabular}{|c|c|c|c|c|c|}
\hline Scales & $\mathbf{N}$ & Mean & Std. Dev. & Skewness & Kurtosis \\
\hline Organizational Commitment & 416 & 3.2151 & .55773 & -.614 & .376 \\
\hline Emotional Commitment & 416 & 3.4980 & .82079 & -.554 & .162 \\
\hline Continuation Commitment & 416 & 2.9391 & .51630 & -.190 & .026 \\
\hline Normative Commitment & 416 & 3.2083 & .72209 & -.462 & -.027 \\
\hline Work Alienation & 322 & 2.5095 & .82517 & .163 & -.597 \\
\hline Meaninglessness & 322 & 2.1744 & .82776 & .511 & -.325 \\
\hline Self-alienation & 322 & 2.7382 & 1.03995 & .155 & -.874 \\
\hline Powerlessness & 322 & 2.6158 & .96585 & .274 & -.420 \\
\hline
\end{tabular}


In Table 3, the descriptive statistics of the scales of organizational commitment and work alienation used in the current study and of their sub-dimensions. The highest mean from among the sub-dimensions of the scale of organization commitment was calculated for the sub-dimension of "Emotional Commitment". Moreover, the highest mean from among the sub-dimensions of work alienation was calculated for the sub-dimension of "Selfalienation". According to George and Mallery (2010), Tabachnick and Fidell (2013), if the skewness and kurtosis values are between +2.0 and -2.0 , then the scale is considered to have a normal distribution and parametric tests should be used (As cited in Eygü, 2018, 844). Thus, as the skewness and Kurtosis values of the scales of organizational commitment and work alienation used in the current study and of their sub-dimensions were calculated to be between +2.0 and -2.0, one-way ANOVA and independent samples t-test were used in the study.

Table 4. Factor Analysis of the Scale of Work Alienation

\begin{tabular}{|c|c|c|c|c|}
\hline $\begin{array}{l}\text { Name of the } \\
\text { Factor }\end{array}$ & Items & & Item Loadings & $\begin{array}{l}\text { Factor } \\
\text { Extraction } \\
(\%)\end{array}$ \\
\hline \multirow[t]{7}{*}{ Meaninglessness } & İY13 & & .754 & \multirow[t]{7}{*}{26.433} \\
\hline & İY8 & & .732 & \\
\hline & İY14 & & .721 & \\
\hline & İY10 & & .685 & \\
\hline & İY12 & & .654 & \\
\hline & İY9 & & .663 & \\
\hline & İY11 & & .641 & \\
\hline \multirow[t]{6}{*}{ Self-Alienation } & İY20 & & .754 & \\
\hline & İY15 & & .723 & \multirow{5}{*}{20.875} \\
\hline & İY21 & & .675 & \\
\hline & İY16 & & .643 & \\
\hline & İY18 & & .622 & \\
\hline & İY17 & & .676 & \\
\hline \multirow[t]{13}{*}{ Powerlessness } & İY19 & & .632 & \\
\hline & İY5 & & .732 & \multirow{7}{*}{16,345} \\
\hline & İY1 & & .694 & \\
\hline & İY4 & & .656 & \\
\hline & İY6 & & .632 & \\
\hline & İY7 & & .623 & \\
\hline & İY2 & & .612 & \\
\hline & İY3 & & .606 & \\
\hline & \multirow{5}{*}{\multicolumn{2}{|c|}{$\begin{array}{c}\text { Sampling Adequacy } \\
\text { Bartlett Test }\end{array}$}} & TOTAL & 63.653 \\
\hline & & & & .876 \\
\hline & & & Chi-square & 1344.20 \\
\hline & & & Df & \\
\hline & & & Sig. & .000 \\
\hline
\end{tabular}

In Table 4, factor analysis of the scale of work alienation is presented. The scale of work alienation was divided into three sub-dimensions called powerlessness, meaninglessness and self-alienation. The original scale has the same sub-dimensions.

Table 5. Factor Analysis of the Scale of Organizational Commitment

\begin{tabular}{llcc}
$\begin{array}{l}\text { Name of the } \\
\text { Factor }\end{array}$ & Items & Item Loadings & $\begin{array}{c}\text { Factor } \\
\text { Extraction } \\
(\%)\end{array}$ \\
\hline Emotional & OB3 & .776 & 27.130 \\
Commitment & OB6 & .754 & \\
& OB1 & .734 & \\
& OB2 & .704 & \\
& OB4 & .695 & \\
& OB5 & .686 & \\
Continuation & OB17 & .723 & 24.250 \\
Commitment & OB14 & .712 & \\
& OB18 & .701 &
\end{tabular}




\begin{tabular}{|c|c|c|c|c|}
\hline & OB13 & & .673 & \\
\hline & OB15 & & .671 & \\
\hline & OB16 & & .664 & \\
\hline Normative & OB8 & & .651 & \\
\hline \multirow{10}{*}{ Commitment } & OB7 & & .714 & 14.323 \\
\hline & OB9 & & .704 & \\
\hline & OB10 & & .653 & \\
\hline & OB12 & & .643 & \\
\hline & OB11 & & .621 & \\
\hline & & \multirow{5}{*}{$\begin{array}{l}\text { Sampling Adequacy } \\
\text { Bartlett Test }\end{array}$} & TOTAL & 65.703 \\
\hline & & & & .801 \\
\hline & & & Chi-square & 1423.44 \\
\hline & & & Df & 81 \\
\hline & & & Sig. & .000 \\
\hline
\end{tabular}

In Table 5, factor analysis of the scale of organizational commitment is presented. The scale of organizational commitment was divided into 3 sub-dimensions called emotional commitment, normative commitment and continuation commitment. The original scale has the same sub-dimensions.

Table 6. Correlation between the Perceptions of Organizational Commitment and Work Alienation

\begin{tabular}{|c|c|c|c|c|}
\hline & $\begin{array}{c}\text { Organizational } \\
\text { Commitment }\end{array}$ & Emotional & Continual & Normative \\
\hline \multirow{2}{*}{ Work Alienation } &,$- 737^{* *}$ &,$- 660^{* *}$ &,$- 599^{* *}$ &,$- 642^{* *}$ \\
\hline &, 000 &, 000 &, 000 &, 000 \\
\hline \multirow{2}{*}{ Meaninglessness } &,$- 584^{* *}$ &,$- 536^{* *}$ &,$- 473^{* *}$ &,$- 499^{* *}$ \\
\hline & ,000 &, 000 &, 000 &, 000 \\
\hline \multirow{2}{*}{ Self-Alienation } &,$- 697^{* *}$ &,$- 605^{* *}$ &,$- 587^{* *}$ &,$- 608^{* *}$ \\
\hline &, 000 &, 000 &, 000 &, 000 \\
\hline \multirow{2}{*}{ Powerlessness } &,$- 638^{* *}$ &,$- 582^{* *}$ &,$- 498^{* *}$ &,$- 562^{* *}$ \\
\hline &, 000 &, 000 &, 000 &, 000 \\
\hline
\end{tabular}

The correlation between the perceptions of organizational commitment and work alienation was tested with correlation analysis. As a result of the analyses conducted, a negative and significant correlation $(p<0.01)$ was found between the perceptions of organizational commitment and work alienation. In other words, with the increasing perception of organizational commitment, the perception of work alienation decreases.

Table 7. The Effect of Organizational Commitment on Work Alienation

\begin{tabular}{|c|c|c|c|c|c|}
\hline \multirow{2}{*}{$\begin{array}{c}\text { Model } \\
\text { Dependent Variable: } \\
\text { Work Alienation }\end{array}$} & \multicolumn{2}{|c|}{$\begin{array}{l}\text { Non-standardized } \\
\text { Coefficients }\end{array}$} & \multirow{2}{*}{$\begin{array}{c}\begin{array}{c}\text { Standardized } \\
\text { Coefficients }\end{array} \\
\text { Beta }\end{array}$} & \multirow{2}{*}{$\mathbf{T}$} & \multirow{2}{*}{$\mathbf{P}$} \\
\hline & B & $\begin{array}{c}\text { Std. } \\
\text { Error }\end{array}$ & & & \\
\hline (Constant) & .666 & .099 & & 6,694 & ,000 \\
\hline $\begin{array}{c}\text { Organizational } \\
\text { Commitment }\end{array}$ & -.678 & .035 &,- 737 & $-19,509$ &, 000 \\
\hline $\mathrm{P}$ & \multicolumn{5}{|c|}{0.000} \\
\hline $\mathrm{F}$ & \multicolumn{5}{|c|}{380.607} \\
\hline Durbin-Watson & \multicolumn{5}{|c|}{1.833} \\
\hline Adjusted $\mathrm{R}^{2}$ & \multicolumn{5}{|c|}{0.543} \\
\hline
\end{tabular}

In Table 15, the effect of organizational commitment on work alienation with regression analysis is shown. Since there was a high correlation between the dimensions of organizational commitment, Durbin-Watson values were 
not between 1.5 and 2.5 and VIF and Tolerance values were not within the desired ranges, they were not included in the model as independent variables. As a result of the analysis, it was understood that organizational commitment has an effect on work alienation. In other words, as the perception of organizational commitment increased, the perception of work alienation decreased. Of the total variance in work alienation, $54.3 \%$ is explained by organizational commitment.

\section{RESULTS}

The concept of organizational commitment, which dates back to the depths of the history of philosophy, has recently gained importance in the organizational context in our country and in the world. The individual's perception of organizational commitment can vary across its dimensions and can be encountered in the form of alienation from work, cynical attitude, not attaching the required importance and a critical point of view. Such cynical attitudes of the individual within the organization lead to both decreasing efficiency in the activities of the organization and to the creation of personnel who are difficult to manage in organizational terms.

Although alienation is a concept inherent in human nature, as old and deep-rooted as human history, its identification with business life is mostly based on the industrial revolution and its aftermath. Of course, it would be possible to observe the negative effects of a period characterized by mechanization, technological developments and the depreciation of the individual's labour as a result of the capitalist order, on the perceptions of employees and their approach to work. It has been observed that instead of identifying himself/herself with the organization in return for his/her effort, the individual cannot grasp the value of himself/herself for the organization in the mechanized, robotic, routine work cycle and is alienated as a result.

In the current study, the relationship between the perceptions of organizational commitment and work alienation of the employees working in the health sector was examined. To this end, a questionnaire was administered to 322 people working in the health sector in İstanbul. In the empirical analyses, regression and correlation methods were employed.

The number of studies investigating the relationship between these two phenomena is highly small. This study, different from the other relevant studies in the literature, includes the analysis of employees working in the health sector in Istanbul. In the previous studies, this population and sample were not addressed. As a result of the analysis, it was determined that there is a negative relationship between organizational commitment and work alienation. In other words, it was observed that as the employees' perception of organizational commitment increased, their level of alienation from work increased as well. Thus, the $\mathrm{H}_{1}$ hypothesis of the study was supported.

It is possible to prevent the alienation of employees by detecting the intra-organizational factors that cause organizational alienation in advance and intervening in possible problems beforehand. The personnel working in the lodging sector, which is an important element of the tourism sector, provide service under great pressure as a result of long working hours and heavy guest traffic. Employees working under pressure are increasingly getting alienated from themselves and their work. In the tourism sector, where the employee turnover rate is high, taking measures to prevent organizational alienation and ensuring the organizational commitment of the employees are one of the important issues that will bring organizational success. Meeting the expectations of the individual in the business environment and making him/her feel that he/she is a part of the organization that works for the purposes of the organization rather than a robot will have an impact on quality in business life, as stated by Gürcü (2012). In the light of the results of the current study and the review of the literature, in the tourism sector, where production is directly dependent on the human factor, managers should follow the organizational or individual activities of their personnel by "seeing", not by "looking". In order to prevent the alienation problem, which can be described as a crisis in both individual and organizational terms, and to eliminate the existing problem, all level managers should be actively involved in intra-organizational communication.

Alienation is a growing problem. For this reason, it is necessary to determine the factors that cause alienation for an employee who has an organizational alienation problem. In this respect, the social opportunities offered by the organization, the protection of the legal rights of the employees, the preparation of in-service training that will increase the job-related qualifications and the organization's providing a suitable work environment for the employee are important issues to be handled. If the perceptions of managers about such problems in the organization are clear, then it can be an opportunity to turn a crisis into an opportunity. For an alienated worker who has isolated himself/herself from his/her environment, exhibiting democratic leadership behaviours and 
directing the employee towards communicating will reduce the effect of the problem, while at the same time, it will over time increase the self-confidence of the employee who is encouraged to communicate. One of the most distinctive features of democratic leadership behaviour is to encourage workers to generate ideas and to participate in decisions and this is a factor that can directly affect the powerlessness dimension of alienation. However, an employee, who is managed with democratic leadership behaviour, will realize that his/her thoughts are cared for and will feel valued. This will prevent alienation and increase organizational commitment.

It is seen in the literature review carried out in detail on the subject that the problem of alienation in connection with relations between democratic leadership, role ambiguity and organizational commitment has not been the subject of research up to now. Investigation of these relations is the scientifically powerful side of the current study. In this respect, it is thought that analyzing the current state of the issue in other branches of the sector is important in terms of bringing the problem to the agenda and coming up with some useful implications. In addition, it is thought that a comparative analysis in which organizational alienation will be investigated more comprehensively in five dimensions rather than in three dimensions as in the current study can be a subject of further research. Researching the subject in relation to different variables will help fill the gap in the literature.

\section{REFERENCES}

Al-Ababneh, M. (2013). "Leadership Style of Managers in Five-Star Hotels and Its Relationship with Employee's Job Satisfaction", International Journal of Management \& Business Studies, C: 3, No: 2, ss. 93-98.

Avcı, U. ve Topaloğlu, C. (2009). "Hiyerarşik Kademelere Göre Liderlik Davranışlarını Algılama Farklılıkları: Otel Çalı̧̧anları Üzerinde Bir Araştırma”, KMU İİBF Dergisi, No: 16, ss. 1-20.

Ayazlar, G. ve Güzel, B. (2014). "The Effect Of Loneliness in The Workplace on Organizational Commitment", Procedia - Social and Behavioral Sciences, C: 131, ss. 319-325.

Az, H. (2017). Relationship between Organizational Commitment and Employee's Performance Evidence from Banking Sector of Lahore. Arabian Journal of Business and Management Review, 7(2), 1-7.

Babür, S. (2009). "Turizm Sektöründe Örgütsel Yabancılaşma: Antalya Beş Yıldızlı Konaklama İşletmelerine Yönelik Bir Araştırma”, Akdeniz Üniversitesi Sosyal Bilimler Enstitüsü, Basılmamış Yüksek Lisans Tezi.

Banai, M. ve Reisel, W. D. (2007). "The Influence of Supportive Leadership and Job Characteristics on Work Alienation: A Six-Country Investigation”, Journal of World Business, C: 42, No: 4, ss. 463-476.

Banai, M. ve Weisberg, J. Y. (2003). “Alienation in State-Owned and Private Companies in Russia”, Scandinavian Journal of Management, C: 19, ss. 359-383.

Behar, R. (2007). "Endüstri İşletmelerinde Çalışma Koşullarının İş Görenler Üzerindeki Yabancılaşma Etkisi ve Bir Uygulama”, Yıldız Teknik Üniversitesi Sosyal Bilimler Enstitüsü, Basılmamış Yüksek Lisans Tezi.

Brannen, M., Peterson, M. (2009). Merging without alienating: interventions promoting cross-cultural organizational integration and their limitations. Journal of International Business Studies, 40(3), 468-489.

Büyükyılmaz, O. (2007). "İşletmelerde Yabancılaşmanın Sosyo-Psikolojik Etkileri ve Türkiye Taşkömürü Kurumunda Bir Uygulama”, Zonguldak Karaelmas Üniversitesi Sosyal Bilimler Enstitüsü, Basılmamış Yüksek Lisans Tezi.

Chiaburu, D., Thundiyil, T., Wang, J. (2014). Alienation and its correlates: A meta-analysis. European Management Journal, 32(1), 24-36.

Eastham, R. S. (2004). "Role Stressors and Intent to Leave: A Study of Hotel General Managers", Master of Human Relations University of Oklahoma, Basılmamış Doktora Tezi.

Güçlü, H. (2006). "Turizm Sektöründe Durumsal Faktörlerin Örgütsel Bağl1lık Üzerindeki Etkisi”, Anadolu Üniversitesi Sosyal Bilimler Enstitüsü, Basılmamış Doktora Tezi.

Hirschfeld, R., Feild, H. (2000). Work centrality and work alienation: distinct aspects of a general commitment to work. Journal of Organizational Behavior, 21, 789-800.

İnce, C. (2013). "Demokratik Liderlik ile İhtiyaçlar Hiyerarşisi Arasındaki İlişkiye Yönelik 5 Yıldızlı Otel İşletmelerinde Bir Araştırma", Akademik Bakış Dergisi, No: 35, ss. 1-15.

Kanungo, R. N. (1979). The concepts of alienation and involvement revisited. Psychological Bulletin, 86(1), 119138.

Kavacık, M., Baltacı, F., ve Yıldız, A. (2013). "Konaklama İşletmelerinde Örgütsel Çatışma ve Örgütsel Bağlılık Arasındaki İlişkiyi Belirlemeye Yönelik Bir Araştırma", Journal Of Alanya Faculty Of Business/Alanya İşletme Fakültesi Dergisi, C: 5, No: 3, ss. 73-85.

Keller Robert. T. (1975). "Role Conflict and Ambiguity: Correlates With Job Satisfaction and Values", Personnel Psychology, ss. 57-64. 
Kılıç, E. (2010). “Örgütsel Bağlılık, Örgütsel Vatandaşlık Davranışı ve Yabancılaşma Arasındaki İlişki- Çağrı Merkezi Çalışanları Üzerine Uygulama”, Uludağ Üniversitesi Sosyal Bilimler Enstitüsü, Basılmamış Yüksek Lisans Tezi.

Mauldin, R. K. (2001). “Alienation: A Laughing Matter”, Utah State Üniversitesi, Basılmamış Doktora Tezi.

Mercan, M. (2016). "Öğretmenlerde Örgütsel Bağlılık Örgütsel Yabanc1laşma ve Örgütsel Vatandaşl1k", Afyonkarahisar Kocatepe Üniversitesi Sosyal Bilimler Enstitüsü, Basılmamış Yüksek Lisans Tezi.

Mete, M., Zincirkıran, M., Tiftik, H., Yalçınsoy, A., ve Pekcan, A. (2015). "Personel Güçlendirme, Örgütsel Bağlılık ve İş Memnuniyeti İlişkisinin Yapısal Eşitlik Modeli ile İncelenmesi: Turizm Sektöründe Bir Araştırma", Bartın Üniversitesi İdari ve İktisadi Bilimler Fakültesi Dergisi, C: 6, No: 12, ss. 137-156.

Meyer, j. P., Allen, N. J. (1991). A three-component conceptualization of organizational commitment. Human Resource Management Review, 1(1), 61-89.

Meyer. J. P., Stanley, D. J., Herscovitch, L., Topolnytsky, L. (2002). Affective, continuance, and normative commitment to the organization: A meta-analysis of antecedents, correlates, and consequences. Journal of Vocational Behavior, 61, 20-52.

Nair, N., Vohra, N. (2010). An exploration of factors predicting work alienation of knowledge workers. Management Decision, 48(4), 600-615.

Namasivayam, K., \& Zhao, X. (2007). "An Investigation of The Moderating Effects of Organizational Commitment on The Relationships Between Work-Family Conflict And Job Satisfaction Among Hospitality Employees in India”, Tourism Management, C: 28, No: 5, ss. 1212-1223.

Netemeyer, R., Burton, S., ve Johnston, M., (1995). "A Nested Comparison of Four Models of The Consequences of Role Perception Variables". Organizational Behavior and Human Decision Processes, C: 61, No: 1, 77-93.

Özdevecioğlu, M. ve Aktaş, A. (2007). “Kariyer Bağlılı̆̆ı, Mesleki Bağl1lık ve Örgütsel Bağl1lığın Yaşam Tatmini Üzerindeki Etkisi: İş-Aile Çatışmasının Rolü”, Erciyes Üniversitesi İktisadi ve İdari Bilimler Fakültesi Dergisi, C: 28, ss. 1- 20.

Özutku, H. (2008). Örgüte duygusal, devamlılık ve normatif bağlılık ile iş performansı arasındaki ilişkinin incelenmesi. İstanbul Üniversitesi İşletme Fakültesi Dergisi, 37, (2), 79-97.

Pelit, E., ve Kılıç, İ. (2012). "Mobbing İle Örgütsel Bağlılık İlişkisi: Şehir ve Sayfiye Otellerinde Bir Uygulama”, İşletme Araştırmaları Dergisi, C: 4, No:2, ss. 122-140.

Phillips, L. V. A. (2001). "A Model Of Alienation From Nursing Work", Virginia Common Wealth University, Basılmamış Doktora Tezi.

Puni, A.; Agyemang, C. B. ve Asamoah, E. S. (2016). "Leadership Styles, Employee Turnover Intentions and Counterproductive Work Behaviours", International Journal of Innovative Research \& Development, C: 5, No: 1, ss. 1-7.

Sarros, J. C.; Tanewski, G. A.; Winter, R. P.; Santora, J. C. ve Denstent, I. L. (2002). "Work Alienation And Organizational Leadership", British Journal of Management, C: 13, ss. 285-304.

Taştan, Ș. İşçi E., Arslan B. (2014). Örgütsel Destek Algısının İşe Yabancılaşma ve Örgütsel Bağl1lığa Etkisinin İncelenmesi: İstanbul Özel Hastanelerinde Bir Çalışma, Pamukkale Üniversitesi Sosyal Bilimler Enstitüsü Dergisi. 19, 121-138.

Terzioğlu, Ö. F. (2014). “Doğu Akdeniz Gıda İşletmelerinde İşgörenin Rol Çatışması ve Rol Belirsizliği Algısının İş Tatmini ve Örgütsel Bağlılık Üzerine Etkisi”, Çağ Üniversitesi Sosyal Bilimler Enstitüsü, Basılmamış Yüksek Lisans Tezi.

Tnay, E., Othman, A. E. A., Siong, H. C., ve Lim, S. L. O. (2013). "The Influences of Job Satisfaction And Organizational Commitment on Turnover Intention". Procedia- Social and Behavioral Sciences, C: 97, ss. 201-208.

Tummers, L.G., Den Dulk, L. (2013). The effects of work alienation on organizational commitment, work effort and work-to-family enrichment. Journal of Nursing Management, 21(6), 850-859.

Uysaler, A. L. (2010). "Örgütsel Yabancılaşmanın Örgütsel Bağlılık İş Tatmini ve İşten Ayrılma Eğilimi ile Bağlantıs1 ve Yabancılaşma Yönetimi”, Gebze Teknik Üniversitesi Sosyal Bilimler Enstitüsü, Basılmamış Yüksek Lisans Tezi.

Uzun, Ö., ve Yiğit, E. (2011). "Örgütsel Stres ve Örgütsel Bağl1lık İlişkisi Üzerine Orta Kademe Otel Yöneticileri Üzerinde Yapılan Bir Araştırma”, Eskişehir Osmangazi Üniversitesi İ̈BF Dergisi, C: 6, No: 1, ss. 181213.

Ünsal A.S., Karahan D. (2011). Yabancılaşmanın İşten Ayrılma Eğilimini Belirlemeye Yönelik Bir Alan Araştırması, Selçuk Üniversitesi İktisadi ve İdari Bilimler Fakültesi Sosyal ve Ekonomik Araştırmalar Dergisi, 15(21), 361-378. 
Weiner, Y., Vardi, Y. (1980). Relationships between job, organization, and career commitments and work outcomes: An integrative approach. Organizational Behavior and Human Performance, 26(1), 81-96.

Yaou, T.; Qiu, Q. ve Wei, Y. (2019). "Retaining Hotel Employees As Internal Customers: Effect of Organizational Commitment on Attitudinal And Behavioral Loyalty of Employees", International Journal of Hospitality Management, C: 76, ss.1-8.

Yavuz, E., ve Tokmak, C. (2009). "İşgörenlerin Etkileşimci Liderlik ve Örgütsel Bağl1lık İle İlgili Tutumlarına Yönelik Bir Araştırma". Uluslararası İktisadi ve İdari İncelemeler Dergisi, C: 1, No: 2, ss. 17-34. 